\author{
Konrad Nowak-Kluczyński \\ Zaktad Historii Wychowania \\ Wydziat Studiów Edukacyjnych \\ Uniwersytet Adama Mickiewicza Poznań
}

\title{
Od znaku „Polski Walczącej” po hasło „FaceBóg” - rola polskiego graffiti w latach 1942-2011
}

\begin{abstract}
Konrad Nowak-Kluczyński, From the "Fighting Poland" Sign to the Slogan "FaceBóg" (FaceGod) /fersbuk/ - the Role of the Polish Graffiti in the Years 1942-2011

Against the general opinion the history of graffiti goes back to the beginnings of civilization. There are numerous examples of graffiti, for instance the inscriptions hollowed with a chisel found on the ancient household artifacts or on the walls. The inscriptions had an informative function but they were also magical. The phenomenon of spray art was widespread in the 1960s and the beginning of the Polish taggers subculture was in the 1980s, although one can find street art during the Second World War. But it is usually neglected or disregarded in the Polish literature. The Anchor - the sign of "Fighting Poland", was placed on pavements, walls, notice boards or train stops of the occupied country. It was the sign of the fight for freedom and independence. As the years passed, the Polish reality was changing and the role of graffiti also changed. Now, it expresses itself in slogans, appeals, messages, drawings, portraits or murals.

The aim of the work is to show the role of the Polish graffiti between 1942 and 2011. The author analyses graffiti in a number of aspects and throughout many years. The author identifies Polish spray art with teenage rebellion, sense of humor, political engagement, commentary or the negation of reality. Moreover, the article focuses on social, psychological or urban aspects of the examined phenomenon and identifies it with widespread modern hip-hop culture.
\end{abstract}

Keywords: history, Polish graffiti, sign „Fighting Poland”

Graffiti, według definicji encyklopedycznej, to spray art, sztuka szablonu, sztuka ulicy, to nie tylko rodzaj techniki i działania artystycznego, ale także zjawisko socjologiczne wyrażone $w$ formie napisów, symboli, haset, malowanych na ścianach domów, murach, miejscach publicznych. Malowane sprayem lub pędzlem przez szablon ${ }^{1}$, wedle definicji

\footnotetext{
${ }^{1}$ Encyklopedia powszechna PWN, Warszawa 2005.
} 
słownikowej to także wizerunki malowane na ścianach domów, murach, parkanach, w miejscach publicznych ${ }^{2}$.

Historia graffiti, wbrew powszechnej opinii, jest „stara jak świat”. Za graffiti uznaje się chociażby wydrążone rylcem napisy, spotykane na pradawnych przedmiotach codziennego użytku czy ścianach. Pełniły one wówczas funkcje informacyjną (nazwa przedmiotu, nazwa geograficzna) oraz magiczną (zaklęcia). Do graffiti zalicza się również egipskie hieroglify ${ }^{3}$. Charakteryzując historię powstania graffiti, należy cofnąc się 15 tysięcy lat, kiedy to ówcześni „grafficiarze” swoje malunki zamieszczali na ścianach grot mieszkalnych Lascaux. Podobne dzieła zostały odkryte w Egipcie i Pompejach ${ }^{4}$. Pierwsze ślady graffiti odnaleźć można w miastach Majów oraz starożytnej architekturze Rzymu, gdzie przeciwnicy władzy carskiej wypisywali na ścianach domów krzykliwe hasła. Graffiti było znane w średniowieczu, swój rozkwit przeżywało w dobie romantyzmu. Jednakże zdecydowanie różniło się od obecnego ${ }^{5}$.

Graffiti na szeroką skalę rozwinęło się w latach sześćdziesiątych XX w. ${ }^{6}$ Było to spowodowane falą młodzieńczych ruchów kontestacyjnych, a ich kolebką stały się Stany Zjednoczone. Ośrodkiem był początkowo Nowy Jork. To właśnie w nowojorskim metrze odbywały się „walki” pomiędzy zbuntowaną młodzieżą a zwalczającą ich działalność nowojorską policją ${ }^{7}$ W Europie ten typ ekspresji upowszechnił się w czasach ekspansji kontrkultury. We Francji graffiti odegrało istotną rolę w okresie rewolty studenckiej „,paryskiego maja" 1968 r. ${ }^{8}$ Stało się sposobem toczenia dyskusji z oficjalną propagandą ${ }^{9} \mathrm{Na}$ początku lat 70. powstały farby w spray'u, w wyniku czego graffiti stało się coraz większe, bardziej kolorowe i co najważniejsze bardziej widoczne, i eksponowane ${ }^{10}$. Wcześniej grafficiarze posługiwali się pędzlami, wodoodpornymi flamastrami. W literaturze przedmiotu dużo uwagi poświęca się nastolatkowi greckiego pochodzenia - Demetriusowi. Kiedy w roku 1971 w „The New York Times” ukazał się artykuł, w którym Demetrius oznajmił, że nie ma takiego miejsca w nowojorskim metrze, gdzie nie zostawiłby swojego śladu, wybuchł ogólny trend na zaznaczanie swojej obecności w różnych publicznych miejscach ${ }^{11}$. „Taki 183”, bo tak podpisywał się Demetrius, stał się od tej pory idolem

\footnotetext{
2 M. Pęczak, Mały słownik subkultur młodzieżowych, Warszawa 1992, s. 29.

${ }^{3}$ P. Potrykus-Woźniak, Słownik nowych gatunków i zjawisk literackich, Warszawa - Bielsko-Biała 2010, s. 61.

${ }^{4}$ P. Piotrowski, Subkultury młodzieżowe. Aspekty psychologiczne, Warszawa 2003, s.81.

${ }_{5}^{5}$ M. Gwozda, Grafficiarze - artyści, subkultura czy wandale?, w: Subkultury młodzieżowe wczoraj i dziś, red. M. Filipiak, Tyczyn 2001, s. 173.

${ }^{6}$ R. Pawlak, Polska kultura hip-hopowa, Karga 2004, s. 24.

${ }^{7}$ P. Piotrowski, op. cit., s. 81.

${ }^{8}$ M. Pęczak, op. cit., s. 30.

${ }^{9}$ B. Prejs, Bunt nie przemija. Bardzo podręczny słownik subkultur młodzieżowych, Katowice-Warszawa 2004, s. 80.

${ }^{10}$ R. Pawlak, op. cit., s. 25.

11 Ibidem, s. 24-25.
} 
nastolatków ${ }^{12}$. To właśnie malowidła Demetiusa określane są mianem pierwszego przejawu nowoczesnego graffiti ${ }^{13}$.

W Polsce, jak i całej Europie, powstanie subkultury grafficiarzy datuje się na lata 8014, dokładniej na lata 1980-1981, w okresie powstawania „Solidarności” i w stanie wojennym ${ }^{15}$. Wówczas graffiti dotyczyło przede wszystkim sytuacji politycznej i było wyrazem więzi z opozycją antykomunistyczną. Często były to wyrażenia obsceniczne bądź humorystyczne. W Europie Wschodniej graffiti stało się znakiem uwolnienia od poddaństwa, zależności, ucisku. Sztuka graffiti dotarła również do Związku Radzieckiego, gdzie w dobie pierestrojki stała się symbolem społecznej emancypacji, zwłaszcza młodzieży w Leningradzie ${ }^{16}$.

W piśmiennictwie źródłowym pomijany jest jednak fakt, że graffiti dostrzec można już w okresie II wojny światowej na ziemiach okupowanej Polski, w postaci znaku „Polski Walczącej”. Literatura przedmiotu skupia się przeważnie na latach 80. oraz 90. W wielu publikacjach dotyczących sztuki ulicy, znaleźć można jedynie krótkie wzmianki dotyczące znaku „Polski Walczącej”, tak jak np. w Słowniku nowych gatunków i zjawisk literackich autorstwa Pauliny Potrykus-Woźniak: graffiti [...] napisy na murach z okresu „Solidarności”, ale także znak „Polski Walczacej” z czasów okupacji, czy pozycji Przemysława Piotrowskiego Subkultury młodzieżowe. Aspekty psychospołeczne: $w$ okresie II wojny światowej stynne byly rysunki, przedstawiajace kotwice, symbol „Polski Walczacej".

Znak „Polski Walczącej” jako symbol walki o niepodległość, miał formę kotwicy. Jej człon w kształcie litery $\mathrm{P}$ symbolizował Polskę, a ramiona w kształcie litery W walkę bądź „kotwicę” jako symbol nadziei odzyskania niepodległości. Napis, w formie graffiti, umieszczany był na chodnikach, murach, tablicach ogłoszeniowych, czy przystankach kolejowych okupowanego kraju. Do najbardziej znanych znaków „P.W.” należał ten znajdujący się na cokole pomnika Lotnika przy pl. Unii Lubelskiej namalowany przez Jana Bytnara „Rudego” z jednej strony i Jana Guta z drugiej. Znak malowano trudną do usunięcia farbą smołową za pomocą malarskich pędzli do malowania mieszkań. Było to zadaniem młodego pokolenia harcerzy ${ }^{17}$. Malowanie kotwic było częścią składową akcji

12 G. Rowiński, Socjologiczno-psychologiczna analiza grup wyznaniowych i subkultur w Polsce. Podkultury i nowe ruchy religijne w Polsce, Warszawa 2004 , s. 61.

${ }_{13}$ M. Golka, Graffiti w poszukiwaniu tożsamości, w: red. M. Golka, Od kontrkultury do popkultury, Poznań 2002, s. 132.

${ }^{14}$ P. Piotrowski, op. cit., s. 81.

${ }^{15}$ G. Rowiński, op. cit., s. 62.

${ }^{16}$ M. Gwozda, op. cit., s. 173.

${ }_{17}$ Vide np. A. Kamiński, Zośka i Parasol. Opowieść o niektórych ludziach i niektórych akcjach dwóch batalionów harcerskich, Warszawa 2009; W. Bartoszewski, 1859 dni Warszawy, Kraków 2008; W. Bartoszewski, E. Lokajski, B. Tomaszewski, red. Z. Lokajska-Domańska, Fotografie z Powstania Warszawskiego, Warszawa 1994; J. Śląski, J. Piesiewicz, Polska Walcząca: 1939-1945, Warszawa 1990; M.M. Drozdowski, S. Mrożewski, Polska Walcząca wobec powstania $w$ getcie warszawskim: antologia tekstów historycznych i literackich, Warszawa 2003; K. Bąkała, Historia symboliczna znakiem, herbem i barwa pisana, Warszawa 2010; M. Wierzbicki, Studia z dziejów harcerstwa 1944-1989, Łódź 2009; Z. Głuszek, „Hej, chłopcy...”. Harcerze Szarych Szeregów w Powstaniu Warszawskim, Warszawa 2001; A. Janowski, Umieć się różnić. Szkice o Aleksandrze Kamińskim, Warszawa 2001; K. Koźniewski, I zawsze krzyż oksydowany... Refleksje nad 
„mały sabotaż” w Warszawie. „Mały sabotaż” polegał m.in. na zrywaniu niemieckich flag, czy pisaniu na budynkach antyniemieckich haseł. Miało to na celu podtrzymywać ludność na duchu i świadczyć o istnieniu organizacji, która toczy walkę z okupantem ${ }^{18}$. Ponadto zadaniami „małego sabotażu” było przeciwdziałanie propagandzie hitlerowskiej, psychiczne gnębienie okupanta, a także karanie, w formie ostrzeżenia, obywateli za nieodpowiednie postawy Polaków wobec okupantów. Ówczesne graffiti w postaci znaku „Polski Walczącej” było nie tylko znakiem trwającej konspiracyjnej walki, ale przede wszystkim pełniło funkcję symbolu polskiej niepodległości ${ }^{19}$. „P.W.” miała charakter informacyjno-ostrzegawczy dla okupanta: „Polska Walczy”. Za współtwórczynię znaku uznaje się ówczesną studentkę historii sztuki na tajnym Uniwersytecie Warszawskim, harcerską instruktorkę, Annę Smoleńską.

Reprodukcja znaku kotwicy Polski Walczącej pojawiła się po raz pierwszy na łamach „Biuletynu Informacyjnego” (pismo konspiracyjne; nr 15) 16 kwietnia 1942 z notatką, którą prawdopodobnie sporządził Aleksander Kamiński. Brzmiała ona: Już od miesiaca na murach Warszawy rysowany jest znak kotwicy. Rysunek kotwicy jest robiony tak, że jego górna część tworzy litere „P”, zaś część dolna-litere „, $W$ ”. Pewna ilość napisów objaśnia, że znak kotwicy jest znakiem Polski Walczacej. Zapoczątkowany być może przez jakiś zespót - znak ten stat się już własnościa powszechna. Co dzień ścierany z murów pojawia się na tych murach na nowo, rysowany przez nieznane tysiace rąk. Sa ulice gdzie znaków jest mniej, ale sa i takie - gdzie widzi się je na każdym domu, na każdej latarni, na chodnikach... Nie umiemy wyttumaczyć popularności tego znaku. Być może działa tu chęć pokazania wrogowi, że mimo wszystko - nie złamał naszego ducha, że jesteśmy, że czekamy tylko na dogodna chwilę. Może na wyobraźnię „rysowników” działa symbolika kotwicy - znaku nadzieji oraz niezawodności? A może tylko przekorna chęć zagtuszenia wrogiej swastyki - własnym, polskim znakiem? Tak czy inaczej - znak kotwicy opanowat stolice i jest prawdopodobnem, że rozpowszechni się po całym kraju. Niech idzie w świat! Niech niepokoi wroga, niech świadczy - że Polska Walczaca żyje i czuwa. Znak „Polski Walczącej”, którego idea narodziła się w Warszawie, z czasem przeniknęła na inne obszary Polski. „P.W.” przetrwała okres wojny, a także jej powojenne zawirowania. Znak kotwicy Armii Krajowej umieszczony został na pamiątkowych odznakach batalionów „Gustaw” - „Harnaś” i „Parasol”20. W czasie okupacji prócz rysunków kotwic, na murach Warszawy pojawiały się napisy: „Śmierć faszystom”, „Pomścimy bohaterów”21.

Ponadto, przemyślnym aktem „,małego sabotażu” były napisy umieszczane na obwieszczeniach niemieckich. Hasło „Pawiak pomścimy” miało przypominać o dokonywa-

\footnotetext{
historia Harcerstwa w Polsce, Kraków 1990; A. Paczkowski, Pół wieku dziejów Polski 1939-1989, Warszawa 1996; B. Wachowicz, Kamyk na szańcu. Gawęda o druhu Aleksandrze Kamińskim w stulecie urodzin, Warszawa 2002 .

18 I i II wojna światowa. Polska i Polacy, red. K. Kunicki, T. Ławecki, L. Olchowik, Warszawa 2010, s. 266.

19 Patrz, np. W. J. Welker, Znaki Polski Walczacej: odznaczenia, orty, oznaki, odznaki, medale, Toruń 1999; W. J. Welker, Symbolika znaków Polski Walczącej: 1939-1989, Toruń 2000.

${ }^{20}$ Zob. N. Davis, Powstanie’44, Kraków 2009, s. 736-737.

${ }^{21}$ M. Jędrzejewski, Młodzież a subkultury. Problematyka edukacyjna, Warszawa 1999, s. 211.
} 
nych przez gestapo zbrodniach w więzieniu Pawiak, w którym to hitlerowcy torturowali polskich bojowników. Pawiak urósł do rangi symbolu znienawidzonych przez społeczeństwo okupantów ${ }^{22}$. Antyniemiecki napis „kaput hycler” miał jednoznacznie kojarzyć się z Hitlerem, wyrażał życzenie jego śmierci. Wódz III Rzeszy został, na zasadzie gry słownej, przyrównany do łapacza bezpańskich psów ${ }^{23}$. Zdaniem Tomasza Sikorskiego, warszawskiego artysty, pierwszym graffiti w Warszawie były figury biało-czarne, namalowane na murze przy skrzyżowaniu ulic Grzybowskiej i Żelaznej przez Włodzimierza Fruczka.

Po wojnie graffiti utożsamiano ze słynnymi napisami „3 razy tak" malowanymi podczas referendum ${ }^{24}$. Referendum ludowe przeprowadzone w Polsce 30 czerwca $1946 \mathrm{r}$. miało być testem popularności rządzących krajem komunistów oraz ich sojuszników. Uczestniczącym w referendum zadano trzy ogóle pytania: Czy jesteś za zniesieniem Senatu? Czy chcesz utrwalenia w przyszłej Konstytucji ustroju gospodarczego, zaprowadzonego przez reformę rolną i unarodowienie podstawowych gałęzi gospodarki krajowej, z zachowaniem ustawowych uprawnień inicjatywy prywatnej? Czy chcesz utrwalenia zachodnich granic Państwa Polskiego na Bałtyku, Odrze i Nysie Łużyckiej? Uzyskane wyniki referendum nie odpowiadały prawdzie z racji różnego rodzaju fałszerstw ${ }^{25}$. Dziś hasło ,3 razy tak" jest postrzegane jako źródło historyczne, występujące jedynie na pustostanach, na zniszczonych czasem niezamieszkałych budynkach.

Jednym z bardziej znanych politycznych graffiti w Polsce był napis „Ziemniaki do ziemi, księża na księżyc". Graffiti to zostało oparte o wydarzenia Marca'68, a dokładniej tyczące się ówczesnego sloganu „Studenci do nauki, pasta do butów”, będących szyderczym rozwinięciem hasła peerelowskiej antystudenckiej propagandy „Studenci do nauki” wymierzonego w uczestników ówczesnego wiecu studenckiego, zorganizowanego na dziedzińcu UW ${ }^{26}$. Hasło „Studenci do nauki” widniało na transparentach podczas wiecu w Hucie Warszawa ${ }^{27}$.

W okresie Polskiej Rzeczypospolitej Ludowej grafficarze nie tylko informowali o swoich politycznych poglądach, ale także zamalowywali szarość, beznadziejność i brud ulic. Do najsłynniejszego szablonu tego okresu zalicza się obrazek z wizerunkiem twarzy Wojciecha Jaruzelskiego i podpisem „Wojtek nie daruje ci tej nocy”28. Podpis był ściśle związany z wprowadzeniem w Polsce, w nocy z 12 na 13 grudnia 1981 r., stanu wojennego. Generał Wojciech Jaruzelski w przemówieniu radiowo-telewizyjnym poinformował Polaków o przejęciu władzy w Polsce przez Wojskową Radę Ocalenia Narodowego. Na ulice wyszło wojsko, obsadzając wszystkie ważne punkty i budynki, co spotkało się ze sprzeciwem ze strony Polaków.

\footnotetext{
${ }^{22}$ I i II wojna światowa..., s. 268.

23 Ibidem, s. 269.

${ }^{24}$ M. Jędrzejewski, op. cit., s. 211.

25 Vide Cz. Osękowski, Referendum 30 czerwca 1946 w Polsce, Warszawa 2000.

${ }^{26}$ B. Prejs, op. cit., s.109.

27 Zob. A. Zamoyski, Polska. Opowieść o dziejach niezwyktego narodu 966-2008, Wydawnictwo Literac-

${ }^{28}$ M. Gwozda, op. cit., s. 174.
} kie 2001, s. 513. 
W 1983 r. Waldemar „Major” Frydrych, współtwórca Pomarańczowej Alternatywy, na warszawskich murach zaczął malować wizerunki radosnych krasnali. Przyjmuje się, iż stylistyka tych obrazków, która odznaczała się na tle politycznych haseł w istocie rozpoczęła historię polskiego graffiti ${ }^{29}$. Dwa lata później pojawiły się pierwsze szablony autorstwa m.in. Tomasza Sikorskiego, Andrzeja Rosołka, Andrzeja Maruszeczki, Szymona Urbańskiego. Za szczyt działalności polskich grafficiarzy przyjmuje się lata 1989-1990, co powiązane było nie tylko z liberalizacją polityczną, ale także z ogólną dostępnością farb w sprayu.

Po 1989 r. polskie graffiti w formie napisów i rysunków było symbolem młodzieżowego buntu, wyrazem poczucia humoru oraz świadectwem istnienia młodzieżowych subkultur $^{30}$. Rysunki były atakiem zarówno na komunę, jak i Solidarność, na Wałęsę, jak i Jaruzelskiego. Na murach pojawiały się hasła: „Komuno precz” lub „Komuno wróć”. Na kościelnych murach wypisywano: „Czarna komuna” czy „Jezus był lewakiem” (socjaliści z PPS-RD) ${ }^{31}$.

W III RP, w 1992 r. powstał United Clan, którego lider X-Man, stał się królem polskiego graffiti. Jak pisze Bogdan Prejs: Szczecińscy writerzy w ciagu kilku lat wypracowali niezwykle barwny i oryginalny styl. W przeciwieństwie do prostych liter Warszawy czy hardcore'owych sreber we wrocławskim stylu, malarze ze Szczecina nie zatrzymali się w rozwoju. Ciagle wzbogacają swój styl, wciagajac do swojej grupy writerów z Gdańska, całego wybrzeża, a nawet z Warszawy ${ }^{32}$. Powszechnie uznaje się, że najlepsze graffiti tworzone są z reguły w dużych miastach. Do europejskiego stylu zalicza się graffiti z Warszawy, Trójmiasta, Szczecina.

W latach 90. XX w. graffiti w Polsce opierało się przeważnie na satyrze i dekonstruowaniu języka przez zabawę. Wyróżnia się następujące przykłady graffiti tego okresu: reklamowe („Łupież i łysina w jednym”), erotyczne („Czerwony kapturek sypia ze śpiącą królewną”), szkolne („Szkoła óczy”; „Szkoła naszym wspólnym więzieniem”), kościelne („Księża na księżyc”, „Bóg i tak był kosmitą”, „Forest Glemp”,33), egzystencjalne („Chce mi się wyć”, „Ludzie myślcie - to nie boli”, ,Jest dobrze”) oraz polityczne („Magister elekt”, „Głosuj na Wałęsę”) ${ }^{34}$. Graffiti polityczne tego okresu związane było z wyborami prezydenckimi w 1995 r. i dotyczyło dwóch kandydatów: Lecha Wałęsy oraz Aleksandra Kwaśniewskiego. Hasło „Magister elekt” dotyczyło wykształcenia tego drugiego, który po wygranych wyborach, już jako prezydent-elekt, mimo wcześniejszych deklaracji, przyznał na łamach czasopisma „Polityka”, że nie zrobił magisterium.

Sprejowcy (grafitomani) uaktywniali się szczególnie podczas tak ważnych wydarzeń politycznych, jakim były i są do dzisiaj wybory nie tylko prezydenckie, ale i parlamen-

${ }^{29}$ M. Pęczak, op. cit., s. 32.

${ }^{30}$ M. Jędrzejewski, op. cit., s. 211.

31 Ibidem.

32 A. Buda, Historia kultury. Hip-hop w Polsce 1977-2002, Głogów 2001, s. 76.

33 Hasło „Forest Glemp” było grą słów, opartą na filmie „Forrest Gump” i postaci ks. kardynała Józefa Glempa, który w marcu 1992 r., po reorganizacji struktur Kościoła w Polsce, pozostał arcybiskupem metropolitą warszawskim, zachowując godność Prymasa Polski.

${ }^{34}$ M. Gwozda, op. cit., s. 175-176. 
tarne. Na wyborczych plakatach dopisywano prześmiewcze komentarze do wyborczych haseł, groteskowe zwroty, malowano gwiazdy Dawida. Podczas wrześniowych wyborów parlamentarnych w 1993 r. na plakatach BBWR z hasłem „Halo, tu Polska! Odezwij się”, na tle różowej słuchawki dopisywano: ,pomyłka”" ${ }^{35}$. Na plakatach UD pod hasłem „Po pierwsze gospodarka” dopisywano ,po drugie Rokita, a po siódme nie kradnij”. Nazwę partii „Unia Pracy” modyfikowano na „Unia do pracy”. Ponadto, na plakatach Kongresu Liberalno-Demokratycznego umieszczano zwroty „złodzieje”, a do podobizny Waldemara Pawlaka dopisywano zwrot „Kargul. Sami Swoi”.

Aspektem społecznym graffiti stał się wówczas i jest do dziś komunikat, a także wolność słowa i obrazu, które pozwalały na komentowanie rzeczywistości. To także indywidualna wypowiedź, komentarz, akt samorealizacji jako aspekt psychologiczny graffiti. To zabawa, przejaw buntu, walka, ironia, protest, próba nawiązania społecznego dialogu. Współcześnie coraz rzadziej spotkać można graffiti polityczne. Hasła: „Polityka mózg zatyka”, czy „Precz z komuną” dawno zostały zamalowane ${ }^{36}$.

Obecnie, do najbardziej charakterystycznych „walków”, jakie pojawiają się na ulicach polskich miast zalicza się graffiti:

- egzystencjalne: „Śmierć samobójcom”, „Nie mam nic do stracenia. Kat”,

- religijne (kościelne): „Chrząszcz brzmi w trzcinie, ksiądz grzmi w gminie”, „Lepiej przepić całą płacę, niż księdzu dać na tacę”, „Nie módlcie się ludzie - forsa decyduje o cudzie”, „Nie bolą was kolana od klękania?”,

- prześmiewcze: „Ależ mnie zażył. Tabletka”, „Jestem przegrana. Kaseta”, „Świat ponury, maluj mury”, „Chcesz mieć sny kolorowe, pijaj wina owocowe”, „Uśmiechnij się, jutro możesz nie mieć zębów”, „Strażak leje na wszystko”, „Gdy dopadła cię niedola, skocz do sklepu, kup jabola",

- erotyczne: „Gdy jedno ciało drugie gniecie, to powstaje ciało trzecie”, ,Jej drabina do kariery ma cztery litery"37,

- polityczne: „Polityka - walka chorych słów”,

- promujące bądź negujące kluby piłkarskie: „Lech Poznań - Wiara Lecha”, „Legia Pany".

Bogdan Prejs w książce Bunt nie przemija. Bardzo podręczny słownik subkultur młodzieżowych do najczęstszych haseł wypisywanych sprayem na murach przez grafficiarzy i hip-hopowców (autor rozróżnia te dwie subkultury) zaliczył: „H.W.D.P.” (jest skrótem od wulgarnego sloganu negującego działalność policji - uważanego za naczelne hasło propagowane przez blokersów i hip-hopowców) oraz „Maluj mury” (najbardziej charakterystyczny napis na murach propagowany przez grafficarzy $)^{38}$.

Pod koniec lat 90. XX w. grafficiarzy zaliczono do odrębnej subkultury. Do głównych przesłanek traktujących o tym fakcie zaliczano: szeroko rozumianą więź środowiskową, wygląd malujących oraz treść komunikatów zawierający informację o konkretnej subkul-

\footnotetext{
${ }^{35}$ M. Jędrzejewski, op. cit., s. 210.

${ }^{36}$ M. Gwozda, op. cit., s. 173.

37 G. Rowiński, op. cit., s. 62.

${ }^{38}$ Zob. B. Prejs, op. cit., s. 105-109.
} 
turze bądź informację adresowaną do konkretnej subkultury ${ }^{39}$. Jednak obecnie dostrzega się, że w Polsce na murach piszą przedstawiciele różnych subkultur: hip-hopowcy, hipisi, szalikowcy, blokersi, chuliganie, punki („Zabij skina”). Sataniści w większości przypadków ograniczają się do malowania odwróconych trzech dziewiątek. Wegetarianie, a także obrońcy zwierząt, na polskich murach ostrzegają, że: „Mordując zwierzęta - zabijasz siebie”, a wyznawcy Kryszny informują, że „Jedynym Bogiem jest Kryszna”40. Graffiti uznawane jest za język „kultury hiphopowej”, na którą składają się kolejno rap, graffiti oraz break dance ${ }^{41}$, a także w zależności od źródła DJ ${ }^{42}$. Graffiti jako jeden z części składowej „kultury hiphopowej”, uznawany jest powszechnie za formę hiphopowej ekspre$\mathrm{sji}^{43}$. Założenia ideologiczne, obyczajowość, kreowany wizerunek, aktywność twórcza to główne cechy młodzieżowych subkultur ${ }^{44}$. Subkulturę należy postrzegać jako wartości i normy obowiązujące w grupie społecznej stanowiącej całość szerszej zbiorowości, odmienne od obowiązujących ogół społeczeństwa. Funkcjonowanie subkultur młodzieżowych jest w dużej mierze uzależnione od sytuacji politycznej, gospodarczej kraju, od szans i możliwości zaspokojenia potrzeb młodzieży ${ }^{45}$. Przynależność do określonych grup społecznych wzbudza społeczną niechęć. Członkowie subkultur są sprawcami przestępstw przeciwko życiu, zdrowiu i mieniu. Ich zachowanie cechuje chęć wyżycia się, szpan, brutalność, chuligaństwo i wandalizm. Młodzież identyfikuje się z grupą ideowo i zewnętrznie. Ideowo, wykazując przez przyjętą ideologię swój stosunek do rodziny, szkoły, społeczeństwa ${ }^{46}$. Zewnętrznie, za pomocą ubioru, niekonwencjonalnych zachowań - upodobań do słuchania określonego gatunku muzyki ${ }^{47}$.

39 M. Gwozda, op. cit., s. 177-178.

${ }^{40}$ M. Jędrzejewski, op. cit., s. 212.

${ }^{41}$ A. Jawłowski, Gry i zabawy hiphopowe. Subkultura młodzieżowa jak wspólnota ludyczna, w: Kultura popularna.Graffitina ekr@nie, red. W. Godzic, Kraków 2002, s. 129.

42 B. Prejs, op. cit., s. 41.

43 A. Jawłowski, op. cit., s. 132.

${ }^{44}$ M. Gwozda, E. Krawczak, Subkultury młodzieżowe. Pomiędzy spontanicznościa a uniwersalizmem, w: red. M. Filipiak, Socjologia kultury. Zarys zagadnień, Lublin 1996, s. 10.

${ }_{45}$ Zob. M. Filipiak, Od subkultury do kultury alternatywnej. Wprowadzenie do subkultur młodzieżowych, Lublin 1999.

${ }^{46}$ S. Kozak, Patologie wśród dzieci i młodzieży. Leczenie i profilaktyka, Warszawa 2007, s. 190-191.

47 Portret socjologiczny grafficiarza nie został sprecyzowany. Nie można bowiem konkretnie wyeksponować cech „twórczej’ jednostki, roli społecznej i środowiska lokalnego, w którym egzystuje. Uproszczeniem stają się stwierdzenia przypisujące grafficiarzy jedynie do środowisk marginalnych, kierując się wyłącznie stereotypami. Nierzadko twórców „,sztuki ulicy” zalicza się do rodzin mieszczańskich czy robotniczych, a „mazanie" staje się wyrazem kontrkultury, której pragną być przedstawicielami. Subkultura grafficiarzy to nastolatkowie będący uczniami podstawówek, gimnazjów, szkół zasadnych. To licealiści i uczniowie techników, to również studenci. Owe wyspecjalizowane grupy, w większości przypadków mają swój teren działania, nazwę, oraz znak firmowy. Ów znak może pełnić rolę symbolu, którym zaznacza się teren, obszar działalności danej grupy. Może to być równie dobrze znak rozpoznawczy służący jak podpis rysunku. Każdy grafficiarz posiada własny pseudonim (tag), którym podpisuje swoją twórczość. Pseudonim służy rozpoznaniu, jest anonimowy dla policji. Na czele zhierarchizowanej podkultury grafficiarzy stoi „king” (król), który na swym koncie ma najwięcej i najlepiej wykonanych „wrzut”. Większość grafficiarzy nie zna się osobiście, ale każdy zna niepisane prawo, dzięki któremu lepsi mogą zamalowywać dzieła gorszych. Charakterystycznym elementem ich ubioru są bluzy z kapturem oraz plecaki służące do przechowywania puszek z farbą czy gotowych do użycia szablonów. Do ich ubioru zalicza się dżinsowe spodnie z szerokimi nogawkami, buty sportowe z wielkimi ,jęzo- 
Według Ryszarda Kapuścińskiego graffiti jest przejawem braku należytej komunikacji w społeczeństwie, sa forma graficznego krzyku. Ktoś chce, aby jego racje zostały dostrzeżone. Ponieważ kryzys komunikacji będzie trwat wiecznie, graffiti będa tak jak ogień, grad, żywiol powodzi. Będa tė̇ istnieć z tego względu, że komunikacja ludzka staje się komunikacja wizualna, a graffiti to kolor, to uderzenie, to próba zagrania na naszych emocjach. I w pewnym sensie jako sygnat, jako znak komunikacyjny, graffiti moga być bardzo użyteczne. Współczesne graffiti utożsamiane jest z buntem, społeczną kontestacją definiowaną jako wyrażanie protestu, kwestionowanie czegoś, podawanie $w$ watpliwość, demonstrowanie, manifestowanie sprzeciwu, zwłaszcza w ruchach politycznych, w kwestiach religijnych, $w$ twórczości artystycznej ${ }^{48}$, to postawa sprzeciwu, niezgody, zakwestionowanie stuszności lub prawomocności [...] przybiera niekiedy forme ruchu społecznego; ruchu sprzeciwu wobec istniejacego typu porzadku społecznego, politycznego lub systemu oficjalnej kultury ${ }^{49}$. Według A. Jawłowskiej kontestacja jest odmową uczestnictwa w zastanej rzeczywistości ${ }^{50}$, według Wincentego Okonia, to podanie pod watpliwość przyjętych poglądów lub zasad, zwykle okazywane w sposób manifestacyjny [...] zjawiska kontestacji pojawiaja się w ruchach religijnych, politycznych, w twórczości artystycznej lub w ruchach młodzieżowych ${ }^{51}$. Według Tadeusza Palecznego kontestacja jest zjawiskiem uniwersalnym, skierowanym na zmianę kultury, oraz wyrażajacym protest przeciw zastanym normom $i$ wartościom.

Mianem graffiti określa się obecnie rysunki, portrety, napisy, znaki umieszczane w większości przypadków na murach w miejscach publicznych. Grafficiarzami, zwanych sprejowcami, są głównie nieletni malujący farbami aerozolowymi (spray) kolorowe obrazy (graffiti - murale) o bardzo różnej treści. Graffiti to „wrzuta” w młodzieżowym slangu. Dla większości ludzi grafficiarze to wandale. Oni sami określają swoją działalność „,sztuką ulicy”52, postrzegając ją jako „ozdobnik swojej muzyki” (hip-hop). Niektórych grafficiarzy zwie się writersami. Nazwa pochodzi od angielskiego słowa „write”, czyli pisać ${ }^{53}$. W początkowej fazie graffiti było napisem, pewnym ciągiem liter. Z czasem, kiedy zaczęto dodawać do nich kontury i wypełnienia stwierdzono, że bardziej nadają się one do oglądania niż czytania. Od tamtej pory zaczęto używać nazwy ,graffiti”54. Graffiti może mieć formę rysunków, haseł umieszczanych na ścianach domów, blasza-

rami”, czapki baseballówki zakładane daszkiem do tyłu. Inne źródła charakteryzują postać grafficiarza jako: szerokie spodnie, czapki bejsbolówki, muzyka hip-hopowa. Ponadto popijaja piwo, a czasem luzują się „,trawka”. Grafficiarze działają głównie nocą, gdyż jak sami twierdzą ,, wasza jest moc, ale nasza jest noc" (odezwa dla policji). Inne źródła stwierdzają, iż w ich skład najczęściej wchodzą uczestnicy i sympatycy najróżniejszych subkultur, glównie nieletni (,, wyrobieni artystycznie”) malujący farbami aerozolowymi kolorowe obrazy (graffiti) w młodzieżowym slangu nazywane ,wrzutami” lub hasła tzw. walki o bardzo różnej treści, w tym i politycznej.

\footnotetext{
48 Encyklopedia powszechna PWN, t. 8, s. 510.

49 M. Pacholski, A. Słaboń, Słownik pojęć socjologicznych, Kraków 2001, s. 88.

50 Zob. A. Jawłowska, Drogi kontrkultury, Warszawa 1975.

51 W. Okoń, Stownik pedagogiczny, Warszawa 1981, s. 138.

52 G. Rowiński, op. cit., s. 61.

53 B. Prejs, op. cit., s. 81.

54 R. Pawlak, op. cit., s. 25.
} 
nych garażach, starych budynkach, betonowych ogrodzeniach, mostach, wiaduktach kolejowych, wagonach pociągów. Graffiti, na tych ostatnich, cieszy się wśród subkultury hiphopowej dużym poważaniem. Ma to związek przede wszystkim z trudnością wykonania takiego malunku: dotarciem do pociągu, a także uniknięciem kontaktu z funkcjonariuszami SOK-u (Staż Ochrony Kolei) ${ }^{55}$, a zwłaszcza wykonaniem dzieła w krótkim czasie. Taki namalowany na pociągu „wrzut”, przemierza całą Polskę, niosąc przesłanie jego autora, a także sławiąc jego sztukę ${ }^{56}$.

Obecnie tworzenie graffiti dzieli się na malowanie ,z ręki”, a więc za pomocą samych farb oraz na malowanie ,z szablonów”, polegające na przykładaniu do ściany wcześniej wykonanych szablonów i pokrywaniu wolnych obszarów farbą (trzecią techniką, rzadziej spotykaną współcześnie jest malowanie pędzlem). Graffiti uliczne wykonywane jest też czasem za pomocą innych technik, np. pędzla i wodnej farby akrylowej, naśladuje się tutaj jednak zawsze efekty uzyskiwane za pomocą „klasycznej” metody z farbami w sprayu. Techniki graffiti są coraz częściej adaptowane przez „poważnych” malarzy do tworzenia ,pełnoprawnych” dzieł sztuki. W tym sensie przez technikę graffiti rozumie się stosowanie farb akrylowych w sprayu oraz szablonów.

Wyróżnia się kilka form subkulturowej działalności grafficiarzy. Formą najbardziej skomplikowaną są rysunki o bogatej kolorystyce. Równie dobrze mogą one mieć charakter własnych przemyśleń, szkiców. Inspiracją stają się motywy z gier komputerowych, symbolika ulubionego zespołu muzycznego ${ }^{57}$. Forma druga przybiera postać napisów, różnego rodzaju haseł. Mogą one mieć charakter polityczny, szyderczy, prześmiewczy, ekologiczny, dotyczący sfery seksu ${ }^{58}$. Owe hasła, w zamyśle ich autorów, mają niejednokrotnie głębsze znaczenie. Ich zadaniem jest zmusić postronnego obserwatora do przemyśleń, refleksji.

Formą graffiti są również przekorne apele, zabawne rymowanki, teksty piosenek, które mają na celu wyśmianie wychowawców i szkoły oraz wyrażenie swojego buntu w stosunku do rodziców ${ }^{59}$. Często na murach szkolnych można zaobserwować graffiti w postaci napisów negujących funkcjonowanie polskiej szkoły, wyrażających dezaprobatę wobec niej, np. „I hate school”. Podpisem natomiast staje się nie podpis twórcy, lecz „ksywka” przydzielona nauczycielowi przez uczniów. Grafficiarze umieszczają swoje dzieła na budynkach prywatnych firm czy punktów usługowych, tworząc w ten sposób specyficzną dla tych jednostek reklamę zewnętrzną, np. strzeżony parking czy skup złomu. Często zatrudnia się ich do zagospodarowania ścian klubów, pubów czy restauracji. Graffiti, w formie haseł obrażających daną drużynę piłkarską, usytuowane są w okolicach obiektów sportowych, stadionów czy boisk przeciwnika ${ }^{60}$. Cechą graffiti jest teraźniejszość. Powody takiego rozumienia są dwojakie. Po pierwsze, wykonuje je młodzież

\footnotetext{
55 A. Jawłowski, op. cit., s. 132.

${ }^{56}$ G. Rowiński, op. cit., s. 62.

57 P. Piotrowski, op. cit., s. 81.

58 Ibidem.

${ }^{59}$ B. Prejs, op. cit., s. 176.

${ }^{60}$ Ibidem.
} 
w odniesieniu do współczesnych zjawisk, ukazując w ten sposób swoje postawy, obawy, szyderstwo, zaniepokojenia. Po wtóre, teraźniejszość przejawia się w szybkości wykonywanych dzieł i ich ulotności ${ }^{61}$. Ówczesne graffiti to dzieła quasi-artystyczne, absurdalne rysunki, bajkowa grafika. Przeważnie dostrzec można tzw. murale, czyli obrazy, których wykonanie pochłania dużo czasu oraz miejsca. Natomiast na pociągach coraz częściej można zauważyć napisy w formie graffiti, tzw. black bustery.

W aspekcie urbanistycznym, graffiti zaliczane jest współcześnie do przejawów przestrzennej dezorganizacji, zaraz obok zjawiska wandalizmu, slumsów, śmieci i pustostanów ${ }^{62}$. Owe przejawy wpływają na wzmocnienie lęku przed potencjalnym zagrożeniem, a także wytwarzają klimat strachu na danym obszarze. Graffiti mające postać wulgarnych zwrotów i haseł, malowane są nie tylko na murach pustostanów, ale także na budynkach mieszkalnych danej dzielnicy dużego miasta, które uważane są przez mieszkańców za miejsca niebezpieczne. Wulgarne napisy bądź zwroty nacechowane ,„patriotyzmem lokalnym”, jak np. „Witamy na slumsach” (Jeżyce, dzielnica Poznania), wzmagają poczucie lęku wśród mieszkańców, natomiast ludzie spoza tego obszaru czują się nieswojo i niebezpiecznie. Jednakże dezorganizacja przestrzenna, niekoniecznie utożsamiana jest wyłącznie z zagrożeniem bezpośrednim. Jest to przekaz ogólny, mówiący o tym, że dany obszar ma charakter prawdopodobnie niebezpieczny ${ }^{63}$. Grafficiarze uważają się za przedstawicieli miejskiej partyzantki artystycznej. Ma to ścisły związek z tym, że działają wbrew zakazom, w konspiracji, a także narażają się na reperkusje ze strony policji oraz Służby Ochrony Kolei ${ }^{64}$.

Współczesne graffiti poddawane jest wieloaspektowej analizie. Uznawane za sztukę bądź wandalizm ${ }^{65}$ wykorzystywane jest coraz częściej w arteterapii, streetworkingu,

${ }^{61}$ M. Golka, op. cit., s. 134.

62 A. Hauziński, Mapy poznawcze środowiska zamieszkania zagrożonego przestępczością, Poznań 2003, s. 58.

${ }^{63}$ Ibidem.

${ }^{64}$ P. Piotrowski, op. cit., s. 82.

${ }^{65}$ Zdaniem Tomasza Szmagiera, autora zdjęć graffiti, umieszczonych w albumie Polskie mury: [graffitisztuka czy wandalizm], graffiti jest i sztuką, i wandalizmem. Sztuką jest w odbiorze indywidualnym, natomiast wandalizmem jako zjawisko. Znana pisarka i poetka, Agnieszka Osiecka, stwierdziła, że według niej graffiti wynika z poczucia słabości młodego pokolenia. Człowiek, który chce zaznaczyć swoją obecność przez wrzask i agresywność kolorów, jest człowiekiem słabym. Może być to związane z tym, że młodzi coraz częściej nie znajdują dla siebie miejsca w świecie ludzi dorosłych. Graffiti to bunt przeciwko dorosłym, zrobienie czegoś wbrew prawu, wbrew obowiązującym zasadom, normom obyczajowym czy prawnym. Zdaniem Zofii Nasierowskiej to szpecenie, brudzenie, robienie na złość dorosłym. Manuel Gerullis, człowiek, który stworzył Wall Street Meeting, która przerodziła się w Meeting Styles, największą i najbardziej prestiżową imprezę graffiti na świecie, w odpowiedzi na pytanie, czym dla niego jest graffiti, odpowiada: Graffiti to moje życie [...] Znajduje $w$ tym sens $i$ samego siebie. Poza tym dla mnie to wspaniała możliwość dla młodych ludzi, żeby zrobili coś kreatywnego. Wymiar artystyczny graffiti wiąże się z ekspresją, a także jakże istotną potrzebą tworzenia obecną w wielu młodych ludziach. Graffiti to sztuka miasta, która znana jest na całym świecie. Wyznacza ona wszędzie takie same kanony tworzenia, obrazowania. Według niemieckich grafficiarzy głupie napisy, bazgroły czy malowanie gdzie się da, to niszczenie cudzej własności i zeszpecenie wyglądu miasta... prawdziwi grafficiarze tego nie robia... Graffiti może być uznane za sztukę, jeżeli jego twórcy wiedzą, w jakich miejscach je umieścić. Zdaniem Alicji Wahl (artysta malarz, właścicielka galerii) graffiti jest tęsknota za sztuka, a ich autorów niespetnionymi artystami, którzy na murach czasem fantastycznie się spetniają, a poziom niektórych prac jest niemal profesjonalny. Sztuka graffiti doczekała się oficjalnych ekspozycji w galeriach, m.in. w Centrum 
w działaniach profilaktycznych ${ }^{66}$, a nawet resocjalizacji więźniów ${ }^{67}$. Problematykę graffiti ocenia się przeważnie $\mathrm{w}$ aspekcie urbanistycznym, pomijając aspekt socjologiczny oraz psychospołeczny. O złożoności problematyki graffiti świadczy fakt, że w 2004 r. „sztuka ulicy” została przedstawiona jako nowy subkulturowy nurt (,Jedną z nowych na polskim gruncie - grup podkulturowych w środowisku młodzieży są sprejowcy, zwani również grafficiarzami”) ${ }^{68}$, by w roku 2010 znaleźć się w słowniku nowych gatunków i zjawisk literackich ${ }^{69}$. Obok pojęcia graffiti zaczęto umieszczać pojęcie antygraffiti, którego rolą jest walka z grafficiarzami, którzy dopuszczają się wandalizmu ${ }^{70}$. W latach 2009-2011 dostrzec można graffiti negujące działalność internetowych portali społecznościowych typu Facebook, Twitter, MySpace czy Nasza-Klasa. Na murach miast w tym okresie pojawiły się, malowane przeważnie z szablonu, hasła: „FaceBóg” czy „Fuckbook” oraz malowane z ręki hasła typu: „Jestem inny. Nie mam konta na naszej-klasie”. Współczesne graffiti coraz częściej przeradza się w murale ${ }^{71}$, czyli wielkie kompozycje, wielkoformatową grafikę na murach. Murale mają za zadanie przyczyniać się do polepszania jakości przestrzennej dużych miast przez umieszczanie ich na brzydkich ścianach kamienic. W 2011 r. w Poznaniu miał miejsce Festiwal Murali - Outer Spacer, w ramach którego pięciu europejskich artystów (Blue, Erosie, Kenor, Remeda, Sam3) malowało pięć

Sztuki Współczesnej w Warszawie jednakże ciągle głównymi galeriami polskiego graffiti są podziemne przejścia.

${ }^{66}$ W filmie Blokersi, w reżyserii Sylwestra Latkowskiego, Eldo Grammatik (polski raper) stwierdza: Wolę iść w nocy, wziąć puszkę farby, niż iść w nocy, wziąć nóż albo iść w nocy i wziać butelkę wina. To jest na pewno lepsze. Jeżeli wiesz, dwóch na dziesięciu chłopaków zamiast wina czy noża, na noc, bierze puszkę farby, to jest już lepiej. Nawet jeżeli nie jest to powszechnie i społecznie akceptowane, i uważane za najmadrzejsze. Na pewno jest to mądrzejsze od tego wina albo od tego noża. A na osiedlu tak jest, że albo sobie poradzisz albo sobie nie poradzisz. Dużo chłopaków właśnie w ten sposób chce sobie poradzić. Ta puszka później zamienia się na stót kreślarski albo na komputer i robienie profesjonalnych rzeczy. Na tej płaszczyźnie, mur i puszka, stają się miejscem, które przyjmuje nazwę prewentorium. To prewentorium funkcjonuje jako schronienie, jako sanatorium zapobiegawcze przed bezpośrednim bądź pośrednim kontaktem ze społecznymi dysfunkcjami, jako ucieczka przed zjawiskami patologicznymi (,zamiast ćpania rysujemy”).

${ }^{67}$ Warsztaty graffiti realizowane w ramach programu resocjalizacyjnego „Jeszcze wszystko przed nami”, miały miejsce w Zakładzie Karnym w Stargardzie Szczecińskim. Projekt graffiti umieszczony został na jednej ze ścian zakładu. Wśród motywów malowanych przez więźniów znalazła się gitara czy patrzące na świat oko. Program przeznaczony jest dla osób odbywających długoterminowe kary pozbawienia wolności, które w jego ramach biorą udział między innymi w dyskusyjnym klubie filmowym, kole modeli kartonowych, klubie informatycznym, dyskusyjnym klubie przeciw przemocy i uzależnieniu oraz w zajęciach koła plastycznego. Według osadzonych biorących udział w projekcie graffiti dzięki barwnej kolorystyce, jest sposobem ożywienia szarej rzeczywistości.

${ }_{68}$ Zob. G. Rowiński, op. cit.

${ }^{69}$ Zob. P. Potrykus-Woźniak, op. cit.

${ }^{70}$ Zjawisko antygraffiti polega na zamontowywaniu kamer, dodatkowego oświetlenia, które mają pełnić funkcję profilaktyczną i zapobiegać powstawaniu ,sztuki ulicy”. Organizuje się akcje zamalowywania graffiti, jednakże, akurat w tym przypadku, wynik jest odwrotny, tzn. im więcej się zamaluje, tym więcej nowych graffiti powstanie. Z drugiej jednak strony, pozostawienie na świeżo wyremontowanej ścianie budynku jednego graffiti, jest jakoby przyzwoleniem do umieszczania tam kolejnych tego typu dzieł. Aby można było usunąć graffiti ze ściany budynku, działania profilaktyczne muszą dotyczyć już materiałów budowlanych, którymi dana ściana ma być pokryta. W tym przypadku, profilaktyka „,antygraffiti” dotyczy pokrycia ścian specjalnym impregnatem bądź przeznaczoną specjalnie do tego celu powłoką, która powstrzyma „,malunek” przed wnikaniem w głąb powierzchni, a także umożliwi jego zmycie bez narażania ściany budynku.

${ }^{71}$ Często w literaturze przedmiotu termin „murale” uznawany jest za synonim graffiti. 
zaniedbanych ścian poznańskich kamienic. Zdaniem organizatorów, Stowarzyszenia Inner Art., ideą festiwalu było obudzenie Poznania z codziennej szarości przełamywanej jedynie tandetą reklam. Za przykład muralu, w literaturze przedmiotu, podaje się kompozycję namalowaną na zachodniej ścianie muru berlińskiego przed jego zburzeniem w 1989 r. Poszczególne jego fragmenty sprzedawane są do dziś jako pamiątka z Berli$\mathrm{na}^{72}$.

Dziś, jak powszechnie się uznaje, graffiti $\mathrm{w}$ formie haseł, niewiele ze sobą niesie. O ile znak „Polski Walczącej” kojarzony jest $\mathrm{z}$ walką i patriotyzmem, o tyle stosowany współcześnie napis „H.W.D.P” jest przejawem buntu pozbawionego merytorycznych przesłanek. Graffiti nie jest już tak politycznie zaangażowane jak kiedyś, nie posiada żadnego „głębszego" wyrazu, nie pełni roli patriotycznego zaangażowania, no chyba, że przyjmuje się definicję patriotyzmu lokalnego, którego wyrazem są oznaczenia poszczególnych dzielnic wielkich miast. Współczesne graffiti przyrównywane jest do języka dziecka, które uczy się formułowania swych pragnień, przekładania ich na konwencjonalne gesty i słowa ${ }^{73}$. Mniej wyszukaną, rodzimą, ale za to bardziej plastyczną formą terminu „graffiti” stało się pojęcie „mazania"74, mazania bez konkretnego celu i pomysłu. Polskie graffiti zostało społecznie „okiełznane”, czego przykładem jest ogrom możliwości jego wykorzystania i ciągle pojawiające się nowe pomysły twórczego zastosowania „sztuki ulicy”.

\footnotetext{
${ }^{72}$ P. Potrykus-Woźniak, op. cit., s. 150-151.

73 A. Leśniewska-Głowacka, Definiowanie świata..., s. 103.

${ }^{74}$ R. Gregrowicz, J. Waloch, Polskie mury: [graffiti - sztuka czy wandalizm], Toruń 1991.
} 
